Original Research Article

\title{
Winning the Customers Over and Again: Investigating Discourse Features in Nigeria Banking Interactions
}

Bartholomew Ayeni

Department of English, University of Ibadan, UI Road, Ibadan, Oyo, Nigeria

Corresponding Author: Bartholomew Ayeni, E-mail: ayeniidowu035@gmail.com

\begin{tabular}{l} 
ARTICLE INFO \\
\hline Article History \\
Received: July 11, 2020 \\
Accepted: August 10, 2020 \\
Volume: 2 \\
Issue: 3 \\
\hline KEYWORDS
\end{tabular}

Politeness, Face, Business

Discourse, Banking interactions

\begin{abstract}
This paper explores the communication strategies employed by service providers in Nigeria banks to gain new and retain their old customers. This is done by looking at the discourse features inherent in banking interactions. The researcher was given the impetus to undertake this study because of the uniqueness exhibited in banking and business discourse. One could easily have drawn a conclusion that, as expected of every business interaction, the banking interaction would be without fuss because of the training employees receive on human relations, but these findings reveal that this is not always the case. However, the fact that employees have more successful interactions is one that cannot be denied, and this success can be attributed to the application of politeness strategies by bank staff. Brown and Levinson's (1987) politeness theory serves as theoretical framework. Eleven texts from bank employeecustomers interactions were purposively selected and subjected to content analysis in order to reveal linguistic strategies employed in them. It is realised that bank employees adopt features like inclusion, directness, informality, face saving features like avoidance of questions, politeness markers, hesitation and taciturnity when interacting with customers. It is also observed that bank employees use hesitation mostly to avoid making absolute statements which could affect customers' negative face. Also, face saving strategies are the most used as employees do everything to save customer from embarrassment and make them feel good. Inclusion strategies by bank employees serve as vital retention device. This affects the choice of code and kinship terms used by bank employees when relating with customers. In the face of the heat with customers, bank employees resort to taciturnity as an avoidance strategy so that they are not held by their words. Politeness markers like 'please' are used even where they do not seem necessary and sorry is not commonly used. In all, bank employees' attempt to treat their customers as kings in line with their training.
\end{abstract}

\section{Introduction}

Research into workplace communication has attracted considerable attention, and both developed and developing countries alike have taken note of those day-to-day activities which make companies successful (Coleman 1989). When it comes to examining the role of language in workplace, linguists have investigated many different domains, most notably language in the courtroom to explore people's resistance to power (eg. Harris 1989, Atkinson 1992), language in doctor-patient interviews to examine consultation skills and their outcomes (eg. Maclean 1989, Heritage and Sefi 1992), and language in corporate organisations (eg. Holmes and Stubbe 2003, Koester 2006). However, findings reveal that not much is done on the linguistic elements present in business discourse. There is therefore a need for more research to be conducted to explain the linguistic features in communication strategies which people employ to maintain relationships in diverse business contexts.

Published by Al-Kindi Center for Research and Development. Copyright (c) the author(s). This is an open access article under CC BY license

(https://creativecommons.org/licenses/by/4.0/) 
This paper will therefore examine the features of banking interaction in ESL context to see how the discourse features contribute to meaning generation in the institutional setting and its impact on customers. The study takes a pragmatic look at the features of business discourse and how this affects interactions between bank employees and their customers. In essence, the discourse analyst is concerned with what language is used for and not the formal properties of language (much as this too is important). He is concerned with the different parts of a conversation. He must pay attention to their different social contexts, their organisation and the process of encoding and decoding the meaning in talks.

The research focuses on the day to day interactions that go on between care agents and bank customers. It takes a holistic look at general conversations in the banking hall to see if these lead to a failed or successful communication between bank staff and their customers. It is realised that relationships are built or destroyed via interactions and the appropriate approach to such interactions goes a long way to decide what happens between customers and their banks. Care agents are expected to employ every polite means in conversation, in order to retain their customers. The research therefore examines discourse features in such conversations and how it attracts or repels customers to such care agents.

\section{Review of related Literature}

Undoubtedly, many scholars have contributed to the study of business discourse. Bargelia-Chappini et al's (2007) definition implies a broad approach to the term: 'Business discourse is all about how people communicate using talk or writing in commercial organisations in order to get their work done'. In order to do this, various genres and domains should be compared: negotiations, business meetings, professional presentations, mediations, and interviews, business-customer communication implying both written and oral communication.' It encompasses every formal conversation (both oral and written) that takes place at workplace. Chiappini and Nickerson (2007) view this term as extremely flexible: 'The label of business communication seems to us best understood as an overarching category encompassing the whole field of communication studies in business settings, therefore, subsuming organisational and management communication and discourse approaches'.

Daniushina (2010) sees business discourse as 'The verbalisation of business mentality, realised in the form of an open multitude of thematically correlated texts on a wide range of business issues, considered in combination with their extralinguistic contexts'. The scholar suggests establishing a separate branch of Applied Linguistic-Business Linguistics, which, in her view, intersects and interacts with many areas: Sociolinguistics, Psycholinguistics, Text linguistics and Functional Styles, Pragmatics, Discourse studies, Cognitive and Communication Theory, Theory of Organisation, Organisational Psychology and Organisational Communication, Management Studies as well as in applied research of teaching and learning Business English as the lingua franca in international business.

Minodoraotilia (2014) asserts that the origin of business discourse can be traced in the LSP (Language for Specific Purposes) studies and is now at the centre of contemporary culture. The writer states that traditionally, the discourses were divided into oral and written but owing to the recent development of information and communication technologies, this division has become obsolete nowadays. He states that related to the area of business discourse, learning Business English as a foreign language requires more than the mastery of grammar rules, it also requires an awareness of various discourse conventions and a strong ability to put these conventions into practice. The scholar concludes by saying that teachers of Business English have many things in common with teachers of general English: they have to be familiar with linguistic development and teaching theories, they have to be aware of contemporary ideas related to their position and role and they have to become familiar with the new technologies which can be used to improve their methodology.

One can deduce from the foregoing that there is a link between general English and business English. An understanding of general English usage with respect to audience, situation, medium and purpose will go a long way to improve business English. Devoting an entire linguistic field for this as suggested by Daniushina would further boost its learning and application as it would enhance communication in workplaces.

\subsection{Customer-employee relationship and overall customer satisfaction}

Customer-employee relationship is crucial to any bank for its strong impact on customer perceptions of service quality and satisfaction. Previous studies on this (e.g Levesque, 1996, Garbarino and Johnson, 1999, Johnson et. al. 2008) suggest two types of customer satisfaction. Overall satisfaction comes from multiple experiences or encounters with the firm. (Bitner and Hubbert, 1994) whereas, encounter satisfaction will result from the evaluation of a single discreet interaction. Bank customers measure their satisfaction based on a series of encounters or ongoing relationship experience with the bank's employees. This corroborates Storbacka et al (1994) who argued that customers' experiences gathered from all service 
encounters influence their overall satisfaction. However, customer-employee interaction is more vital in some countries (Netherlands, Italy and Kenya) than in other parts of the world where people do not like to be involved in personal interactions (Gremler and Gwinner, 2000). In Bangladesh, as personal relationships hold more influence on customers, it may be assumed that the customer-employee relationships have stronger impacts on customers' mind for their satisfaction than those countries where personal relationship is not an important factor. Findings of prior research studies (Gremler and Gwinner, 2000, Macintosh, 2009) also endorse the view that strong interactions with employees will have positive influence on the customer's mind, leading to satisfaction.

\subsection{Business interaction and related work}

A lot of works has been done on customers' interaction in business generally and banks. Wayla (1996) studied the Kenyan banking discourse and outlined the strategies that the interactants apply in their conversation and the effects they have on banking interaction. It is evident from the study that the structure of Kenyan banking discourse and strategies were influenced by both verbal and non-verbal forms of communication. The Nigerian situation is not different as customers get directives through instructions pasted on walls and hanging in the banking hall, coupled with bank employees adopting extralinguistics and non-linguistics features such as smiles and taciturnity when relating with customers. The current research work however investigates features of discourse that enables successful interactions between bank employees and customers.

Koksal (2000) in his work asserts that to enhance effective cross-cultural communication in spoken business context, the communicators should have socio-pragmatic and pragma-linguistic information/competence to be able to identify the pragmatic content of the message. According to the scholar, the absence of this leads to pragmatic failure in communication. This current study however looks at banking interaction to see how such pragmatic failures could be avoided, especially by bank employees who need to explain and educate the customers on changes that could occur through changing banking policies. Anderson and Nielson (2001) address the communicative platform of banks as pursuers of relationship marketing strategies. They assert that with the increased competition in the financial sector, relationship marketing has become an important part of general bank marketing. They however claim that so far little focus has been on the communication of the marketing brand, with respect to the bank's communicative starting point for pursuing such strategies.

Chan (2002) carries out a study on relationship building and interactivity, looking at customer relationship building via different interaction channels in retail banking. In this exploratory study, two major channels of customer-bank interactions were studied according to their degree of human intermediation and machine/computer intermediation. From the result of the focus group study, it was found that face-to-face interaction with bank officer in the branch is the most preferred interaction format. The present study looks at how relationship is built between care agents and bank customers during such face-to-face interaction and the features of such discourse.

Voutsas and Heinrich (2011) write on enhancing the banking customer value proposition through technology-led innovation and here they analysed the new customer requirements towards banks. The authors state that customers are more aware of their rights and the available service providers at their disposal. As such, they talk about the importance of service providers luring their customers with quality service provision. The use of technology to achieve this is one of the things they stressed in this write up.

Abdur-Razzaque and Fatima (2012) write on bank customers' satisfaction through banking interaction. According to them, growing competition among Bangladesh banks makes it imperative for bank management to explore the impact of service quality and customer involvement on satisfaction during face-to-face interactions between the front-line bank employees and customers. The paper reports the findings from a survey of bank customers on these issues and tests several hypotheses pertaining to them. In their view, research findings will help understand the impact of service quality, customer involvement and most importantly, the effect of rapport on overall satisfaction in the face-to-face banking, the most conventional banking mode in Bangladesh. Their interesting findings reveal that customers are more influenced by personal involvement for rapport building behaviour with frontline employees than service quality. Presumably, involvement with employees acts as re-enforcement later for developing good rapport. The Nigerian situation is however different. Quality service is what determines customers' relationship with frontline employees. 


\section{Methodology}

\subsection{Research design}

This study is designed to analyse, from a discourse perspective, banking interactions between customers and bank employees in Akure, South-West Nigeria, with the intent to examine strategies employed by care agents to win new customers and retain old ones. It also attempts to contribute to and enrich the understanding of banking practices and the role language plays in banking.

\subsection{Population}

Akure is the biggest and most populated town in Ondo state and it is also the capital of the state. The UN World Urbanisation Prospect in its 2020 estimation puts the population of Akure at 665,524 people (World population review 2020). Ondo is tagged a 'civil servant' state as a way of saying that the state is not industrialised. The state could however boast of development in terms of agriculture, health facilities and education. Also, there are lots of petty trading, with markets and lock-up shops in virtually every corner of Akure. Forty sample data is collected for this research out of which eleven were used and it comprises bank employees and customers' business interactions from each of the ten banks that are selected. The reason for this figure is to enable qualitative analysis and to avoid unnecessary repetition.

\subsection{Akure: rationale for its choice}

The choice of Akure for this study is tied to the fact that people from every part of the country are represented here, especially with Army and police barracks located in the city. Akure is a city whose population continues to increase daily. Also, there are few foreigners around acting as expatriates, especially in the construction sector. The researcher's in-depth knowledge of the town and its people also propels this decision.

\subsection{Rationale for the choice of banks}

The choice of commercial banks for data collection is because they are the ones that deal more with customers because of the role they perform in the society. This is apart from growing competition among such banks. Banks like the Central Bank, Bank of Agric., Bank of Industry, Mortgage banks are usually owned by government and as such are not opened to much competition, if any.

\subsection{Sampling frame}

The study employs purposive sampling technique. Purposive sampling is non-probability sampling that is done with purpose in mind. It is through this technique that the researcher gets samples from the bank employees and the customers. Purposive sampling enables the researcher to identify the needed samples from the conversations.

\subsection{Data collection procedure}

Data is collected by use of tape recorder. The researcher used audio recording to obtain the verbal data. Through observation, the researcher can account for such things as tone and intonation, gestures and facial expression among other non-verbal and paralinguistic features. In addition, notebooks were used to take down other observations that were made through non-participatory mode.

Because of the sensitive nature of banking halls, permission was sought from the management of each bank through a letter of introduction in order to take note of the daily conversations between bank employees and their customers. This was not granted and as such, the researcher had to adopt other strategies, which include having business in the banks daily for the period of the data collection and interviewing few customers outside the banking halls. To ensure that the data obtained through recording is free from biases, the researcher employed the social network approach to create confidence between him and the informants. This minimised the observer's paradox because it builds trust with the respondents. It also increased the chances of observing in a prolonged informal interaction without suspicion (Milroy 1987).

Data used for this study were selected from a collection of forty interactions saved for analysis. The researcher purposely selected the conversations that are relevant to the study. The data was analysed using qualitative approach to data analysis. The notes made by the researcher from observation were availed at this stage to supplement the recorded data. The qualitative approach is then used to describe the discourse features and communication strategies used. The research is structured in such a way that the evidence also bears on alternative rival explanations and enables us to identify which of the competing explanations is most compelling empirically. It also means that the researcher did not simply look for evidence that supports his favourite theory: he also looked for evidence that has the potential to disprove his preferred explanations. 


\section{Result and discussion}

\subsection{Face to face interactions}

The Nigeria banking hall is usually a beehive of activities, especially at the early hours of the day and shortly before the closing period in the afternoon. Customers range from people coming to make cash deposits to those coming to make withdrawals. Others come for activities which include, but are not limited to opening account, bill payment, complaint, enquiries. Despite ATMs and other POS services, most transactions take place in the banking hall.

Duncan and Moriarty (1998) point out interactive relationships result in retention of more customers. Like most business meetings, face to face interaction is the most common and most effective form of interaction in the banking services. Even in the use of machines, bank employees are still alerted to certain issues by customers, some of which include the ATM running out of cash or a customer needing a bank official to guide him/her on how to use the machine. Most face to face interaction naturally begins with greetings. Kuang, David, Lau and Ang (2011) attempt to show that politeness can be gauged through these two features of conversations; appropriate greetings at the openings and closings. According to them, openings and closings are both important to features of face-to-face interactions since both elements suggest that acknowledgement and recognition of the other party have been fulfilled. This accounts for what some bank security men do at the entry and exit points of their banks. It is observed that this greetings in Nigeria banks is however determined by the following factors;

i. Age - The Nigerian culture sees greetings as a show of respect and the younger of two interactants is expected to greet first. Bank employees are not expected to wait for their customers to greet them first but in most cases, the age difference factor is a major determinant of who starts the conversation with a greeting.

ii. Familiarity - There are customers that are well known by bank employees, either because of their financial worth, the length of time they have been dealings with the bank or their generosity. Such customers do not only receive a special form of greetings but special treatment from the bank officials.

iii. Situations (complaint vs enquiry) - Customers tend to have time to exchange pleasantries depending on what brought them to the bank. Customers who came to make enquiries begin the conversation with greetings while those who came with complaints don't tend to respond even when greeted by bank staff.

iv. Customer's vs employee's mood - It's easier for conversations to take the usual opening and closing rituals when a happy customer meets with a happy staff. However, such rituals are sometimes not seen between customers and staff late in the afternoon when there are so many people on the queue to attend to and it's almost closing hour. It doesn't matter how they try to hide it, staff tend to show their exhaustion and seeming frustration at this time, especially after dealing with so many difficult customers from the start of the day. There are cases where greetings do not take place at all.

\subsection{Language}

Customers who troop into the banking halls in Nigeria come from every walks of life. They range from the educated to the not that educated and the uneducated. Nigeria has English as both its official and national language but is a multilingual/multi-ethnic and multi-cultural country, seeing that she has over 500 languages and over 250 ethnic groups. It is safe therefore to conclude that English is the language for workplace and the language used by bank staff and customers. This is however not completely the case as there is the use of Pidgin English, especially to relate with the uneducated and the use of the local languages as a way to reach out to or familiarise with everyone in order to create an atmosphere that is homely and not too official. Elugbe and Omamor 1991 describe Nigerian Pidgin as English-based or English-related because most of its vocabulary is derived from English. A Pidgin language is generally reduced "in the direction of whatever features are common to the languages of all those using the Pidgin, for mutual ease in use and comprehensibility, thus arriving at a kind of greatest common denominator" (Hall, 1996). Hudson asserts that "each Pidgin is of course specially constructed to suit the need of its users which means that it has to have the terminology and constructions needed in whatever kind of context" (2000).

A common trait among the Yoruba English users from South-Western Nigeria and the Igbo English users from South-Eastern Nigeria is the ability to carry out a blend of their local language and the English language in a string of conversations. This ability to switch and mix code is one that bank officials use in getting along easily with some of their customers. For a country where good spoken English is one of the proofs of one's educational level, most speakers take pride in switching and mixing codes to show that they are not push-overs. 
In all, the banking hall is one environment that calls for the right comportment, just like religious houses. People (both customers and staff) are expected to be civic in their approach to issues. The burden is more on the bank staff who are expected to protect the public image of the bank. For this reason, they do everything to avoid creating chaotic situations in the banking hall. The findings of this research reveal that the bank employees have good business interactions with their customers, except in few cases. From the texts, one can conclude that bankers employ every means to make their customers want to come back for business. Even where there's a breakdown in communication, the researcher observes that a senior banking official always steps in to pacify customers, in the belief that customers are never wrong.

*Key: BC (Bank Customer) BE (Bank Employee)

\section{Text 1}

Context: Customers pay bills in the bank and this is the case of a customer who wants to pay for subscription for his cable Tv.

BC: Good morning, I came to pay for DSTV.

BE: Please go upstairs, ask for Ronke.

BC: Okay (goes upstairs)

$\mathrm{BE}:$ Yes?

BC: I came to pay for DSTV.

BE: Okay, how much are you paying?

BC: One thousand eight hundred naira.

BE: Can I have your card number? Please fill it here

BC: Okay (fills out the card number)

BE: (Issues receipt): All right, you can go. Your account will be credited shortly. Just leave it at channel 157, that is, African Movie Yoruba.

\section{Text 2}

BE (Pushing teller back to payer): You will have to fill another teller. Where account name is written, write the name of the person that owns the account you are paying into.

BC: Ah! I thought it is the type of account: whether savings or current.

BE: No. Also, your name is what you write for depositor's name. Then you don't fill the last column since you are not paying up to a million naira.

$\mathrm{BC}$ (with a smile): Thank you very much $O$. My son had been the one paying the money, but he travelled.

\section{Face saving as politeness strategy by bankers}

One of the relevant issues in interlanguage pragmatic is the concept of face and politeness which relates to FTA (face threatening act). Attention to these concepts is one of the key successes to any business relationships. According to Brown and Levinson (1978, cited in Bousfield, 2008), "face is something that is emotionally invested and that can be lost, maintained or enhanced" (p. 35). "Face consists of two related elements; namely positive face and negative face: Positive face is an individual's desire to be liked, approved of, respected and appreciated by others; negative face is an individual's desire not to be impeded or put upon, to have the freedom to act as one chooses" (Thomas, 1995, p. 169).

One politeness strategy commonly used by bank employees is saving their customers' face. Meeting this face need could be by making customers feel recognised or welcomed, avoiding questions that could embarrass such customers. This strategy is seen in the data above.

In text 1 , the avoidance of questions by the bank employees is a face-saving strategy. The assumption that there is a shared situational knowledge (SSK) between the bank employees and customer is also to save the customer's face. What the bank 
does is accept money for DSTV subscription, but the customer demanded to pay for DSTV as if to buy the gadget or any other product. Not asking for clarification and the use of presupposition by the bank employees is a face-saving strategy here. Such avoidance strategy according to Brown and Levinson is to maintain harmony and undamaged face between interactants.

In text 2 we realise that customers tend to give more information about themselves than is required if they are well treated. The smiles on the face of the customer during the interaction, coupled with the show of gratitude, are tied to the face-saving lecture she received from the bank employee. The customer could not hide her naivety and left the bank feeling better. This agrees with Yule (2006:119) definition of politeness as 'showing awareness of and consideration for another's face.

\section{Text 3}

Context: Account update and enquiries into transactions relating to customer's account is one of the reasons customers come to the bank. Situations like these calls for customer's education by bank staff.

BC: Sister good morning $o$.

BE: Good morning, welcome.

BC: I come do BVN (pushes a paper forward).

(I came for Bank Verification Number registration)

BE: You don do am before abi you just wan do am?

(Have you registered it elsewhere or this is the first place?)

BC: I don do am for one bank before but dem say make I come collect am. $B C$ :

(I had done it in one other bank but was told to come and collect it.)

BE: No, you go go there go bring am make we register you here.

$B E$ :

(No. You have to get the number from where you registered, bring it here for update)

BC: But...

BE: See, my system show say you don do am for another place. (See, my system shows that you have registered elsewhere) So, go there make them give you the number So, go there and get the number and bring it here for make you bring am here. I go add am. update)

BC: Okay. (Leaves the bank)

Text 4

BE (smiling): Hmn, daddy welcome sir. How was your trip? What about mommy?

$B C:$ We are fine. Jo mo ran driver mi pe ko

(Please, I sent the driver to see if those people

ba mi wo boya awon people yen ti san owo yen.

have paid the money.

O de ni wan ti san.

He then said it had not been paid.)

$\mathrm{BE}$ : Igba wo ni yen sir?

(When was that sir?)

BC: This morning. Wan de pe mi pe wan transfer owo before 10 leni.

(They called me that they transferred money before 10am today.)

BE: A je pe wan ti san ni yen. Sebi e ma $\mathrm{n}$ ri alert?

$B C:$ Yes, but se e mo, igba mi oro network.

Moni ko ma je pe e send e ti mi o ri ni.

BE: Eje $n$ check boya wan ti credit account yin.

BC: Okay. O se dear.
(That means they have not paid it. You do receive alert?)

(Yes. But you know the issue with bad network sometimes. I felt you may send it but I didn't receive it.)

(Let me check if your account has been credited.)

(Thank you dear) 
BE (punches system): Boya ke tun pe wan.

Tori ko ti si transaction kan kan lori account yin leni

BC: Okay. Ma tun pe wan. O se dear.
(Maybe you should call them again.)

(Because there has not been any transaction on your account today)

(I will call them again. Thank you dear)

\section{Inclusion Strategy}

The major problem with Pidgin is that of acceptability and low social rating that it faces generally in Nigeria. This perhaps is why Mafeni (1971: 99) argues that "Attitudes to pidgin are complex and ambivalent. Many Nigerians, although they use pidgin as a register in certain familiar contexts, are nevertheless ashamed to be associated with the language in public . . ." Other problems include the view of the elite that pidgin is a debased form of standard English and thus a language for the lower class and the "unenlightened" as well as the threat posed by English as a dominant language in Nigeria (see Fawehinmi 1987). Despite this negative view of Pidgin, bank customers employ the language as a strategy to accommodate customers. In the conversation in text 3 above, the bank customer addresses the employee as 'sister' even though they are not related in any way. Such term is a sign of respect for her and as a response she changed her code to suit the conversation. Such meaning extension by the customer is deliberately to get the attention of the bank employee. On her part, a change of code is to accommodate the customer. Giles (1971) Communication Accommodation Theory (CAT) account for such inclusion strategy adopted by this bank employee.

Most of the kinship status in Yoruba land is formed by the base of people's idea about society and good behaviours, just like Forshee (2006) conveys of the Indonesians. Inclusion strategies employed by bankers include, but is not limited to code switch, code mix, meaning extension and observation of cultural and societal norms. These are seen in the texts above. In text 4 , the bank employee's show of concern is an indication of knowledge of the customer beyond business relationship. To talk about his trip and 'mommy' could well represent what seems like an after-sale service by marketers, which makes the customers come back to them again and again. The employee's decision to also change her code to suit the customer's is a mark of respect and an inclusion strategy. This is apart from going the extra mile to help him confirm if his account had been credited and the subsequent advice she gave him.

\section{Text 5}

Context: The demand for Bank Verification Number (BVN) was introduced to check financial activities in the country. It demanded registration at one bank and an update in other banks where the customer has accounts.

BC: Good morning, I came for BVN registration.

$\mathrm{BE}$ : Please sit down. Have you registered it elsewhere or this is the first time?

BC: I have registered with First Bank.

$\mathrm{BE}$ : In that case, all you need to do is bring the number given to you there for us to update here.

BC: They are yet to give me the number. They said I should come back for it.

BE: Okay, when you get the number, bring it here. You don't have to register here again.

BC: Okay. Thank you.

\section{Use of politeness markers}

Hughes and Naunton (2007) see politeness markers as expressions added to the utterance to 'show deference to the addressee and to bid for cooperative behaviour'. The most obvious example of a politeness marker in English is please, but there are others, e.g., if you wouldn't/don't mind, tag questions with the modal verb will/would following an imperative structure (Close the door, will you/would you?), etc. Currently, politeness is not only used to show good etiquette in general daily conversation but is also applied in business field. Because of the competition in the business industry, giving the best service quality from politeness perspective becomes a significant factor to attract customer's attention. Two major politeness markers are examined in the data above. The use of 'please' when asking the customer to sit down makes it more of a request than a command. Asking the customer to sit down shows acceptance and adding 'please' indicates a polite acceptance and recognition of his person. This is one of the ways bank employees make their customers feel good. Also, educating their customers rather than expecting them to know what they are supposed to do is a sign of maintaining harmony in conversation. 


\section{Text 6}

Context: Bank operations in Nigeria are carried out more within the banking hall than outside. Unfortunately, adequate provisions are not made for customers' comfort. This leads to lots of frustration on the part of the customers, especially in the face of delays.

BE (Security personnel): Hello sir, why are you standing here?

BC: I came for Western Union, but the man said the network is bad.

BE: You can come back later or hang outside; they have started complaining that you have been standing there for long.

BC: You should be more concerned that I have nowhere to sit rather than ask me to hang outside. Or how is it my fault that network is bad?

BE: Please go outside. (Customer angrily leaves banking hall)

\section{Face Threatening Acts (FTAs)}

One of the relevant issues in interlanguage pragmatic is the concept of face and politeness which relates to FTA (face threatening act). Attention to these concepts is one of the key successes to any business relationships. Brown and Levinson (1987) describe negative face as the want of every competent adult member that his actions be unimpeded by others. Banks employees flout this, not just on the basis of wanting to keep with bank policies but on the grounds of their inability to manage their customers effectively. Instances of this can be seen in text 6 above. The security official is not in any way bothered about the face need of the customer. The opening greetings is just formal and even the use of the politeness marker 'please' in the end is just a necessity. Much as the security personnel above can be said to be acting on instruction, the ease with which he ordered the customer out does not show any sign of concern for the customer's 'face' need. Despite the customer's complaint, the employee didn't even consider a third option or an explanation. It reveals here that features like 'sir', 'please' are not always indicators of politeness. The way they are used by interlocutors is what determines what they stand for. According to Renkema (1993 cited in Null, 2008) "five possible strategies for performing FTAs were outlined according to their relative degree of face threat which, in turn, may reflect the degree of politeness: 'Do the FTA on record without redressive actions (the least polite)'; 'Do the FTA on record with redressive actions addressing positive face'; 'Do the FTA off record'; 'Don't do the FTA' (the most polite strategy)" (p. 79). The security personnel is not concerned whether the customer feels embarrassed that he is marched out of the banking hall. He only wants to please those who employed him, perhaps in order to retain his job.

\section{Text 7}

Context: Banking policies change from time to time and banks are expected to inform their customers of such changes. Most customers are not updated on these changes until they appear in the bank.

BE: You can't transfer funds from your account here.

BC: Why?

BE: You need to go to the branch where you opened the account.

BC: You can't tell me that. I transfer funds from your branch even in Abuja. How can you now tell me that I cannot transfer from my account from Akure because the account was opened in Lagos?

BE: You can use the POS or the ATM for such transfer, but on the counter... I am sorry ma.

$\mathrm{BC}$ : (angrily begins to leave) You people are not serious in this bank. You make issues out of virtually anything.

\section{Pragmatic failure}

One of the factors that impede efficient communication is pragmatic failure. Although in some cases pragmatic failure lacks serious consequences, and, on the contrary, results in rather funny and anecdotal misunderstandings, in other cases it has more dramatic repercussions by causing misunderstandings that may result in puzzlement, surprise, astonishment, frustration, embarrassment or anger. In extreme cases, it may even produce interactive conflict, cultural friction, communication breakdown, unfair and unjustified attribution of personality traits with subsequent negative labelling and stereotypes or contribute to the perpetuation of discrimination as a consequence of very different 
interactive norms across speech communities. (Thomas 1983; Beebe and Takahashi 1989; Kasanga 2001; Kasanga and Lwanga-Lumu 2007). In fact, deviations from the expected or usual communicative practices in a community or sociocultural group are judged differently depending on the degree of error or flaw perceived (Riley 2006: 314). Part of the research areas on pragmatic failure include requests (e.g. Blum-Kulka 1988; Blum-Kulka and Edward 1987; Færch and Kasper 1989; Harlow 1990; Kasanga 1998; Lwanga-Lumu 2002), and refusals (e.g. Beebe et al. 1990; Kwon 2004). There is pragmatic failure among interlocutors when the intended meaning is misunderstood. An explanation would go a long way to make the meaning clearer. Such use of directness serves as an imposition on the customer and affects their negative face. Customers believe that they have a right to their money and that the bank is only helping them keep custody of it. A simple explanation from the bank employee on the reasons or possible reason why the customer could not transfer funds from other branches of the bank could have cleared the air in the text above. The use of the negation 'can't' made it seem like impossibility and this got the customer angry, especially because she had been doing it before. If the reason is due to a new directive to the banks, it behooves on the bank employee to politely explain to the customer. There are times when customers get confused over banks' refusal to allow them do things the way they have always done it. This is worst when nobody is giving them any reason for this. Taking the pain to explain things to customers would make meaning clearer.

\section{Text 8}

Context: There are banking rules that cannot be flouted for whatever reason. Authorisation over any account is strictly the preserve of the signatory/signatories to the account.

BC: I am Pastor John Arifalo. I want statement of account for this account (hands a sheet over to the cashier).

$\mathrm{BE}$ : Are you a signatory to the account?

BC: No, but I have just been posted to head the branch.

BE: Um, Sorry pastor, we can only give statement of account to signatories to the account. Maybe you should tell them to come and collect it so they can give it to you.

BC: Okay, I will ask them to do that. But can I know how much we have in the account?

BE: Erm, no sir. We can only reveal that to signatories to the account.

$\mathrm{BC}$ : All right. (Stands up and leaves)

\section{Use of Hesitation markers}

At present, there is no uncontested theory about the function of hesitation markers (Künzel 1997:51-52), although some theories centre on their pragmatic or social function in discourse. For example, Maclay and Osgood (1959:42) attributes hesitation markers partly to the speaker's desire to keep his or her turn of speech. If the speaker's silent pause is too long, the chance that the listener will interrupt increases. The scholars theorize that the function of hesitation markers is to create time for verbal planning in speech, like the unfilled pause. Rochester (1973) hypothesized that hesitation markers are indications of time for the speech production apparatus to search for the next word, phrase, or idea. Schachter et al. (1991) and Christenfeld (1994) found that hesitation markers occur when a speaker is faced with an option or a challenging choice. Hesitation is to enable speakers maintain the floor while they are trying to recollect things. For bank employees, this is especially when educating customers on information and they need to keep the turn until they are done. Hesitation is however not for this purpose alone and this we see in text 8. Here it serves as a good politeness strategy. Speakers use it when they don't want to be blunt or make absolute statements. The bank employee here tries to save the positive face of the customer and the use of the hesitation marker Um and Erm is one strategy he adopted. Meanwhile the choice of 'pastor' is to keep the revered status of the customer. Despite turning down the demand of this customer, the bank employee still saved the customer's positive face by recognising him. The average Japanese drags the word 'eto' and possibly keeps tapping their head while pondering on a response. The truth here is that they sometimes already know their response but would not want to 'slap' it on the face of their listener, especially if it has to do with turning down requests. It is a way of reducing the negative effect of such rejection on the listener. 
Text 9

Context: Bank customers are usually educated on banking processes as they approach their banks over such issues.

Account opening is one such areas where they get such education.

BC: Please I want to open an account with your bank.

BE: Ok. Is it a savings or current account?

BC: Savings account.

$\mathrm{BE}:$ All right.

$\mathrm{BE}$ : Is it a salary account or you just want it for personal purpose?

$B C:$ I just want to open it so that I can be saving money in it.

BE: Okay.

BE: All you need to do is come with two passport photos (coloured)...

BC: $O K$

$\mathrm{BE}$ : Your national ID card, driver's license or voter's card...

$\mathrm{BC}$ : All right

$\mathrm{BE}$ : And a current NEPA bill. Do you have them here?

BC: No...

BE: Um.

BC: But I can bring them tomorrow.

$\mathrm{BE}$ : Ok, bring them along tomorrow and we will open an account for you.

\section{Discourse markers as backchannels}

Carter and McCarthy (1997:12) refer to backchannels as 'noises (which are not fully words) and short verbal responses made by listeners which acknowledge the incoming talk and react to it, without wishing to take over the speaking turn'. In text 9, the bank employee uses 'okay' and 'all right' to acknowledge the customer while the customer uses 'all right' as an indication that the bank employee is understood. Sometimes in discourse, such marks are used to show resignation, but in such cases, extra linguistic features like a sigh always accompanies it. ' $U m$ ' with a nod could mean understanding or agreement while ' $U m^{\prime}$ ' with a sigh could just show resignation. The Japanese participants in Cutrone's (2005) study did not seem to consider their frequent interjections to be an imposition to their interlocutors (The average Japanese continuously nods and utters the word hai or hai hai at times to show speakers that they are following the conversation). Rather, according to the reasons given by many Japanese participants, the primary function of their frequent backchannels was instead to facilitate a harmonious atmosphere in the conversations. In this way, the Japanese participants did not seem to see their backchannel behaviour, consisting of frequent speech overlapping backchannels, as affecting the negative face of their interlocutors; rather, they believed such a behaviour to be accentuating the positive face of their interlocutors. This is consistent with the generalisation that the Japanese use the back-channeling behaviour to maintain harmony in conversations. Carter and McCarthy also opine that backchannels have an important affective role they play in conversation, indicating a responsive and sympathetic listener.

Text 10

Communication is effective when interlocutors take turns to speak and listen to each other. Bank employees listen to customers' requests or complaints and one way to understand them better is by asking questions for the purpose of clarity. The customer does the listening at this time.

$\mathrm{BC}$ : I submitted a letter last week demanding that my account be closed and the money be transferred to another bank. But the other bank had not alerted me.

$\mathrm{BE}$ : Were you given a form to fill?

BC: No

BE: You only dropped a letter. What about the account the money is to be paid into?

BC: I also left the account details with the lady.

BE: All right, there's a form you are required to fill. Your letter must also indicate, not just your intention to close your account but a request that the balance in it be transferred to another account. I will look into it and tell you what next to do. Meanwhile, take a seat there.

BC: Okay

\section{Turn taking}

Only two interlocutors are involved in each interaction, so turn taking patterns are consistent: $A$ (taking the role of information receiver) normally ask a question and B (taking the role of information giver) answers. Sacks et al. argue 
that conversation is an elemental piece of social organization, regulated by social norms that prescribe one speaker at a time but allow open participation. The model they suggested consists of turn units and rules that operate over those units. The end of such a unit constitutes a 'transition relevance place' or TRP. The rules specify:

If the current speaker $\mathrm{C}$ selects the next speaker $\mathrm{N}$, then $\mathrm{C}$ must stop, and $\mathrm{N}$ should start. ('Selection' could involve address terms, gaze, or in the case of dyadic conversation defaults to the other.)

If $\mathrm{C}$ does not select $\mathrm{N}$, then any participant can self-select, first starter gaining rights to that next unit.

If no other party self-selects, $\mathrm{C}$ may continue.

Further details are often requested by information givers and answers to questions are usually longer, with information givers providing more than one alternative in some cases.

In text 10, both interactants took turn to make a request and give answers to requests made. This is because of the probable situation created by the bank employees and a level of informality displayed.

Again, interrogating and educating bank customers is one format for a successful banking discourse. Customers may come in enraged but if they are listened to and questioned for the purpose of clarity, they leave the bank better than they came in. The situation in the text above is an example of this. Customers love being carefully listened to as this leaves them with a feeling of acceptance and recognition. One turn taking device by bank employees is attentive listening and questioning. Acknowledging customer's complaints and giving them assurance makes customers feel better as displayed in text above.

\section{Text 11}

Context: One way bank staff retain their customers is to meet their needs, albeit without recourse to compromise on bank directives.

BE (Placing cheque in front of him): Can I have your ID card?

BC: Seriously, I got out of home before I realised that I didn't ....

BE (Interrupts): You need to tender your ID card for me to pay you. You can go home and bring it naw.

BC: Honestly, my place is far and ....

BE (Interrupts): There's nothing I can do. On the other hand, if you have an account with the bank you can see the lady over there to confirm your identity. (Customer goes to the other care agent).

BE: What is your name and account number? (Customer provides details).

$\mathrm{BE}$ (Punches the system in front of her): Okay, you were a staff of Wexford College.

BC: Yes, and that was my salary account.

BE: (To colleague) Kunle, e le sanwo fun.

(To customer) You can go, he will pay you.

BC: Thank you so much.

(Kunle, you can pay him.)

\section{Terminal overlapping}

Terminal overlapping occurs when two speakers try to speak at the same time. Latching refers to a point in conversation where there is no pause between turns and even a slight overlap. Both are natural features of conversation and demonstrate our sensitivity to transition relevance place (TRP) (Sacks, Schegloff and Jefferson 1974). In text 11, overlap is used as a mark of finality. There are things that bank employees cannot compromise. In this case, it is making payment without confirming the identity of the cheque holder. However, to save his customer's face, the employee left an alternative which paid off for the customer. The conversation can be said to have ended on a good note because the customer realised that the overlap did not result from imposition but is an adherence to the bank's standing order. Such overlap from bank employees is however affected by factors such as customers' social status, age, etc. Overlaps are sometimes positive in that they bring the speaker back on track. So, it could serve as a corrective measure in conversation and not a form of imposition tied to superiority on the part of the listener.

\section{Conclusion}

The banking sector, like most workplaces, welcome people from all walks of life and as such it is not out of place to find the human nature being exhibited, both by employees and customers. The study reveals that politeness is a major communication strategy in banking discourse. This is shown in both verbal and non-verbal communication cues. Banking interactions are not adversarial like that of the courtroom or conversational like the media. They are rather formal, sometimes friendly and purely business-like. This research reveals that contrary to expectations from bank officials by their customers, there are communication breakdowns caused by bank staff. It is therefore suggested that 
banks look into it to strengthen their relationship with their customers. In all, it is realised that bank employees do all they can to make their customers feel good and by so doing, are able to retain such customers despite their shortcomings. This strategy has enabled smooth interaction.

\subsection{Limitations}

Much as the texts above represent interactions from every commercial bank from where data was collected, the research was conducted in South-West Nigeria. Thus, conversations could take a different turn in other parts of the country due to cultural differences. Also, some banking activities are constant (people constantly deposit and withdraw money) while some come with time. As of today, BVN registration is no longer a major issue in banking activities in Nigeria. It therefore means that there is the need to investigate banking activities again and again to see how it revolves and how this affects interactions between bank staff and customers. Also, with daily innovation via technology, investigations can be carried out on how banking interactions are affected by technological mediation.

\section{Acknowledgement}

The researcher would like to acknowledge Dr Ayo Osisanwo of the Department of English, University of Ibadan for his supervisory role and some banks whose staff were willing to be of help, howbeit in ways that would not flout security standards.

\section{About the author}

Bartholomew Ayeni holds a master's degree in English from the University of Ibadan, Nigeria and his thesis focus was on the effect of language use on business relationship. The author's interest is in text and discourse analysis, with meaning interpretation in view. He currently guides Japanese/English speakers in building confidence in their speaking ability.

\section{References}

[1] Abdur-Razzaque, M. \& Fatima, J. (2012). Understanding the role of service quality, customer involvement and rapport on overall satisfaction in Bangladesh banking service. Unpublished paper. Wales: University of New South

[2] Anderson, H. \& Nielson, E. (2001). Making friends with your money? A semiotic analysis of relationship communication strategies in the financial sector. Hermes Journal of Linguistics 2:1-6.

[3] Atkinson, J. (1992). Displaying neutrality: Formal aspects of informal court proceedings. In Paul Drew \& John Heritage (eds.), Talk at work: interaction in institutional settings. Cambridge: Cambridge University Press. 199-211.

[4] Bargiela-Chiappini, F. \& Harris, S. (2006). Politeness at work: Issues and challenges. Journal of Politeness Research 2: 7-33.

[5] Bargiela-Chiappini, F., Nickerson, C. \& Planken, B. (2007). Business discourse. Basingstoke, UK, Palgrave: Macmillan.

[6] Beebe, L. \& Tomoko, T. (1989). Do you have the bag? Social status and patterned variation in second language acquisition. In Susan Gass, Carolyn Madden, Dennis Preston \& Larry Selinker (eds.), Variation in second language acquisition (Vol. 1 : Discourse and pragmatics), 103-125. Clevedon: Multilingual Matters.

[7] Beebe, L., Tomoko, T. \& Robin, U. (1990). Pragmatic transfer in ESL refusals. In Robin Scarcella, Elaine Andersen \& Stephen D. Krashen (eds.), Developing communicative competence in a second language, 55-71. Rowley: Newbury House.

[8] Blum-Kulka, S. \& Edward, A. (1987). Lexical-grammatical pragmatic indicators. Studies in Second Language Acquisition 9(2). 155-170.

[9] Blum-Kulka, S. (1988). Interpreting and performing speech acts in a second language: A cross-cultural study of Hebrew and English. In Nessa Wolfson \& Elliot Judd (eds.), Sociolinguistics and language acquisition, 36-55. Rowley: Newbury House.

[10] Bousfield, D. (2008). Impoliteness in interaction. Amsterdam. Philadelphia: John Benjamins.

[11] Brown, P. \& Levinson, S. 1987. Politeness: Some universals in language usage. Cambridge: Cambridge University Press.

[12] Carter, R. \& McCarthy, M. (1997). Exploring spoken English. Cambridge University Press.

[13] Chan, S. (2002). Relationship building and interactivity: An exploratory study on cooperative customer relationship building via different interaction channels in retail banking. Unpublished paper: manuscript received November 20, 2002.

[14] Christenfeld, N. (1994). Options and ums. Journal of Language and Social Psychology Vol.3.192-199.

[15] Coleman, H. (1989). Working with language: An introduction. In Hywel Coleman (ed.), Working with language: A multidisciplinary consideration of language use in work contexts. Berlin: Mouton de Gruyter. 263-296.

[16] Cultrone, P. (2011). Politeness and face theory: Implications for the backchannel style of Japanese L1/L2 speakers. Language Studies Working Papers 3: 51-57

[17] Daniushna, V. (2000). Business linguistic and business discourse. Calidoscope 8.3: 241-247

[18] Duncan, T. \& Morirty, S. (1998). A communication-based marketing model for managing relationships. Journal of Marketing 62: $1-13$ 
[19] Elugbe, B. \& Omamor, A. (1991). Nigerian Pidgin: Background and Prospects. Ibadan: Heinemann Educational Books.

[20] Færch, C. \& Kasper, G. (1989). Internal and external modification in interlanguage request realisation. In Juliane House, Blum-Kulka, S. \& Kasper,G. (eds.), Cross-cultural pragmatics: Requests and apologies, 221-247. Norwood: Ablex.

[21] Fawehinmi, P. (1987). Communication in Pidgin in Nigeria: Origin, Problems, and Prospects. In S. Unoh (ed.), Topical Issues in Communication Arts 71-87. Uyo: Modern Business Press.

[22] Forshee, J. (2006). Culture and customs of Indonesia. London, England: Greenwood Press

[23] Garbarino, E. \& Johnson, M. (1999). The different roles of satisfaction, trust and commitment in customer relationships, Journal of Marketing 63:70-87.

[24] Giles, H. (1971). Communication accommodation theory. In W.B. Gudykunst (ed.), Theorising about communication and culture. Thousand Oaks: Sage. 121-148.

[25] Gremler, D. \& Gwinner, K. (2000). Customer-employee rapport in service relationships. Journal of Service Research 3:82-104.

[26] Hall, R. (1966). Pidgin and Creole Languages. London: Cornell UP. Holm, J. An Introduction to Pidgins and Creolesi. Cambridge: Cambridge UP, 2000. Print.

[27] Harlow, L. (1990). Do they mean what they say? Sociopragmatic competence and second language learners. The Modern Language Journal 74(3). 328-351.

[28] Harris, S. (1989). Defendant resistance to power and control in court. In Hywel Coleman (ed.), Working with language: $A$ multidisciplinary consideration of language use in work contexts. Berlin: Mouton de Gruyter.

[29] Heritage, J. \& Sue, S. (1992). Dilemmas of advice: Aspects of the delivery and reception of advice in interactions between health visitors and first-time mothers. In Paul Drew\& John Heritage (eds.), Talk at work: Interaction in institutional settings. Cambridge: Cambridge University Press. 359-417

[30] Holmes, J. \& Stubbe, M. (2003). Power and politeness in workplace. Harlow, U.K.: Pearson

[31] Hudson, R. (2000). Sociolinguistics. 2nd ed. Cambridge: Cambridge UP, 2000. Print.

[32] Hughes,J., \& Naunton J. (2007).Business result(Intermediate). Hungray: Oxford University Press.

[33] Johnson, M., Sivadas, E. \& Garbarino, E. (2008). Customer satisfaction, perceived risk and affective commitment: an investigation of directions of influence. Journal of Services Marketing. 22.5:353-362

[34] Kasanga, L. (1998). Requests in English by second language users. ITL, Review of Applied ～Linguistics 119-120. 123-153.

[35] Kasanga, L. (2001). Intercultural sociolinguistics and communication research in South Africa: Its relevance to academic settings and the service industry. Southern African Linguistics and Applied Language Studies 19. 253-273.

[36] Kasanga, L. \& Lwanga-Lumu, J. (2007). Cross-cultural linguistic realisation of politeness: A study of apologies in English and Setswana. Journal of Politeness Research 3(1). 65-92.

[37] Koester, A. (2006). Investigating workplace discourse. London: Routledge

[38] Koksal, D. (2000). Pragmatic approach to cross-cultural communication in the business world. Unpublished paper: Canakkale Onsekiz Mart University, Turkey

[39] Kuang, C., David, M., Lau, S. \& Ang, P. (2011). Openings and closings in front counter transactions of Malaysian government hospitals. The journal of the South East Asia Research Centre for Communications and Humanities. 3.1:13-30.

[40] Künzel, H. (1997). Some general phonetic and forensic aspects of speaking tempo. Forensic Linguistics 4.48-83.

[41] Kwon, J. (2004). Expressing refusals in Korean and in American English. Multilingua 23(4). 339-364.

[42] Levesque, T. \& McDougall, G. (1996). Determinants of customer satisfaction in retails banking. International Journal of Bank Marketing. 4.7:12-20

[43] Lwanga-Lumu, J. (2002). Internal request modification by first and second language speakers. Journal for Language Teaching 36(3-4). 289-304.

[44] Macintosh, G. (2009). The role of rapport in professional services: antecedents and outcomes. Journal of Service Marketing. 4.7:12-20

[45] Maclay, H. \& Osgood, C. (1959). Hesitation phenomena in spontaneous English speech. Word 15.19-44.

[46] Maclean, J. (1989). Approaches to describing doctor-patient interviews. In Hywel Coleman (ed.), Working with language: A

Multidisciplinary consideration of language use in work contexts. Berlin: Mouton de Gruyter. 263-296

[47] Mafeni, B. (1971). Nigerian Pidgin. In J. Spencer (ed.), The English Language in West Africa 95-112. London: Longman.

[48] Milroy, M. (1987). Observing and analysing natural language: A critical account of social linguistic method. Oxford Basil Blackwell Ltd

[49] Minodoraotilia, S. (2014). Business discourse and teaching English. Annals of Constantin Brancusi, University of Targu Jiu, Economy Series, Special Issue 2014-Information society and sustainable development

[50] Renkema, J. (1993). Discourse studies an introductory textbook. Philadelphia: John Benjamins Publishing Company.

[51] Riley, P. (2006). Self-expression and the negotiation of identity in a foreign language. International Journal of Applied Linguistics 16(3). 295-318.

[52] Rochester, S. (1973). The significance of pauses in spontaneous speech. Journal of Psycholinguistic Research 2.51-81.

[53] Sacks, H., Schegloff, E. and Jefferson, G. (1974). A Simplestic systematics for the organisation of turn-taking for conversation: Language. 50:696-735

[54] Schachter, S., Christenfeld, N., Ravina, B. \& Bilous, F. (1991). Speech disfluency and the structure of knowledge. Journal of Personality and Social Psychology 60.362-367. 
[55] Storbacka, K., Strandvik, T. \& Gronroos, C. (1994). Managing customer relationships for profit: The dynamics of relationship quality. International Journal of Service Industry Management. 5.5: 21-38

[56] Thomas, J. (1983). Cross-cultural pragmatic failure. Applied Linguistics 4(2). 91-112.

[57] Thomas, J. (1995). Meaning in interaction. London: Longman.

[58] Voutsaa, K \& Heinrich, C.(2011). Enhancing the banking customer value proposition through technology-led innovation. Accenture Magazine. 4:1-5

[59] Walya, E. (1996). Kenyan banking discourse: Structure, strategies and their effect on banking interaction. Unpublished M.A thesis. Nairobi: Kenyatta University

[60] World population review. (2020). Akure population (Demographics, Maps, Graphics). (online) accessed on $4^{\text {th }}$ August 2020 at https://worldpopulationreview.com

[61] Yule, G. (2006). The study of language. New York: Cambridge University Press 